\title{
ANALISIS KEBERLANJUTAN USAHA UMKM DI PROPINSI BANTEN
}

\author{
Yudi Nur Supriadi \\ STISIP Yuppentek, Universitas Pendidikan Indonesia \\ yudinur_supriadi@yahoo.co.id
}

\begin{tabular}{l}
\hline Keyword \\
\hline Implementation of Generic \\
Strategy, Sustainability of UMKM \\
Business, Competitive Advantage \\
Strategy, Company Resources
\end{tabular}

Abstract

This study aims to analyze the variables of strategy implementation of generic learning strategies to the sustainability variables of SMEs business, this study provides a good understanding of theoretical and managerial steps that are not done by entrepreneurs of SMEs. The success of the business will be ensured to survive in the midst of industrial processing and weakening the economy both regionally and globally. Example of study I 70 SMEs using SME cluster system in the processing industry in Banten Province. Data processing techniques using questionnaires. To test the predefined relationship model, the researcher uses a 23.00 analysis tool that can be used together (AMOS). The variables generated from the generic strategies of competitive strategies against the significant variables of MSME sustainability and have a positive effect on the sustainability of SMEs business. This research can give meaning for the sustainability of UMKM business in order to survive in global competition with big industry today and future

\section{PENDAHULUAN}

Usaha Mikro Kecil dan Menengah (UMKM) dalam pembangunan ekonomi daerah menjadi sangat penting, peran penting dan strategis UMKM dalam pertumbuhan ekonomi dan penyerapan tenaga kerja, UMKM juga berperan dalam mendistribusikan hasil-hasil pembangunan. UMKM juga telah terbukti tidak terpengaruh terhadap krisis. Ketika krisis menerpa pada periode tahun 1997 - 1998, hanya UMKM yang mampu tetap berdiri kokoh (LPPI:20I5) [I].

Dengan melihat peluang dan kontribusi serta kenyataan yang ada peran UMKM terhadap perekonomian, maka maka dipandang perlu adanya grand strategy pengembangan melalui pemberdayaan UMKM yang menjadi sumber pertumbuhan baru perekonomian Indonesia, dalam hal dapat berperan dalam : (I). Mensejahterakan masyarakat, (2). Membuka lapangan pekerjaan, (3). Wahana pemerataan pembangunan untuk mengatasi kesenjangan pendapatan antar masyarakat, antar wilayah serta antara pedesaan dan perkotaan yang mempu mengurangi arus urbanisasi, (4). Pasar input dan output hasil-hasil produk UMKM, (5). Penghasil devisa, (6). Peningkatan pendapatan nasional (Renstra Kemenkop RI: 2012) dengan demikian terlihat jelas adanya kontribusi nyata sektor Usaha Mikro, Kecil dan Menengah (UMKM) terhadap produk domestik Regional bruto (PDRB) khususnya di Propinsi Banten, paling tidak dalam kurun waktu lima tahun terakhir sangat terasa.

Badan Pusat Statistik Propinsi Banten mencatat adanya peninkatan kontribusi sektor UMKM dari 57,84 persen menjadi 60,34 persen. Tak hanya itu, sektor UMKM juga telah membantu penyerapan tenaga kerja. Serapan tenaga kerja pada sektor UMKM tumbuh dari 96,99 persen menjadi 97,22 persen dalam periode lima tahun terakhir. Sehingga berdampak pada pertumbuhan ekonomi di provinsi Banten yang terus mengalami peningkatan. Hal ini bisa dilihat dari perkembangan Produk Domestik Regional Bruto (PDRB) nominal pada tabel dibawah ini 
Tabel. I Produk Domestik Regional Bruto Provinsi Banten Atas Dasar Harga BerlakuMenurut Lapangan Usaha (miliar rupiah), 2013 - 2016

\begin{tabular}{|c|c|c|c|c|c|}
\hline \multicolumn{2}{|r|}{ Lapangan Usaha/ Inufustriaf Origin: } & 2013 & 2014 & 2015 & 2016 \\
\hline \multicolumn{2}{|r|}{ (1) } & (2) & (3) & (4) & (5) \\
\hline A & $\begin{array}{l}\text { Pertanian, Kehutanan, dan Perikanan } \\
\text { Agriculture, Forestry, and Fishery }\end{array}$ & 22670,34 & 24944,45 & 28385,01 & 31592,19 \\
\hline B & $\begin{array}{l}\text { Pertambangan dan Penggalian } \\
\text { Mining and Quarrying }\end{array}$ & 3404,62 & 3728,80 & 3864,24 & 4082,59 \\
\hline C & $\begin{array}{l}\text { Industri Pengolahan } \\
\text { Manufacturing Industry }\end{array}$ & 140949,17 & 148763,97 & 160514,61 & 168397,88 \\
\hline D & $\begin{array}{l}\text { PenRadaan Listrik dan Gas } \\
\text { Elcctricity and Gas Supply }\end{array}$ & 5437,89 & 11000,96 & 13319,28 & 12406,42 \\
\hline E & Pengadaan Air/ Water Supply & 307.16 & 331,55 & 365,45 & 399.93 \\
\hline F & Konstruksi/ Construction & 34612,03 & 41875,07 & 47767,08 & 52125,62 \\
\hline \multirow[t]{2}{*}{$\mathbf{G}$} & Perdagangan Besar dan Eceran, dan & & & & \\
\hline & $\begin{array}{l}\text { Reparasi Mobil dan Sepeda Motor } \\
\text { Wholesale and Ketail I rade }\end{array}$ & 18783,51 & 53728,63 & 58139,16 & 61611,08 \\
\hline$H$ & $\begin{array}{l}\text { Transportasi dan Pergudangan } \\
\text { Iransport and Warehousing }\end{array}$ & $28723,9 n$ & 39398,55 & $485 R 6,87$ & 55336,48 \\
\hline 1 & $\begin{array}{l}\text { Penyediaan Akomodasi dan Makan } \\
\text { Minum/ Accomodotion Supply }\end{array}$ & 8583.56 & 9996,37 & 11231.26 & 12327.21 \\
\hline J & $\begin{array}{l}\text { Informasi dan Komunikasi } \\
\text { Intormation and Communication }\end{array}$ & 13573,11 & 15600,75 & $16,923,35$ & 18486,07 \\
\hline$\kappa$ & Jasa Keudrigan/ Firnancial Services & 10883,26 & 11928,24 & 13404,44 & 15765,56 \\
\hline L & Real [state/ Real [state & 27018,15 & 29789,61 & 33843,10 & 37308,17 \\
\hline $\mathrm{M}, \mathrm{N}$ & Jasa Perusahaan/ Busincss Scrvices & 3671,00 & 4242,91 & 4895,55 & 5448,12 \\
\hline n & $\begin{array}{l}\text { Administrasi Pemerintahan, } \\
\text { Pertahanan dan Jaminar Susial } \\
\text { Wajih/ Fnuernment Administration } \\
\text { and Defence }\end{array}$ & 7205,52 & 8278,76 & 9467,01 & 10562,92 \\
\hline$p$ & Jasa Pendidikan/ Education Scrvices & 11955,55 & 13607,58 & 14998,80 & 16414,76 \\
\hline n & $\begin{array}{l}\text { Iaca Kesphatan dan Kegiatan Snsial } \\
\text { Heculth urid Sucjul Services }\end{array}$ & 4395,35 & 4912,01 & $540 /, 60$ & 5928,95 \\
\hline \multirow[t]{2}{*}{$\mathrm{R}, \mathrm{S}, \mathrm{T}, \mathrm{U}$} & Jasa lainnya/ Other Services & 5663,98 & 6612,29 & 7430,19 & 8099,95 \\
\hline & PDRB & 377836,08 & 428780,07 & 478543,97 & 516326,90 \\
\hline
\end{tabular}

Sumber : BPS Propinsi Banten Tahun 2016

Data peningkatan PDRB Provinsi Banten dari tahun ke tahun terus meningkat dalam kurun waktu 2013-2016, secara nominal PDRB Provinsi Banten bertambah 138.490 miliar rupiah, dari 377.836 miliar pada tahun 2013 menjadi 516.326 miliar rupiah pada tahun 2016 atau meningkat sebesar 73\%. Hal tersebut dapat menunjukkan bagaimana peran UMKM sangat dominan dalam pertumbuhan ekonomi Indonesia. Sehingga pemberdayaan UMKM merupakan sesuatu yang sangat penting dalam upaya meningkatkan pertumbuhan perekonomian di Indonesia. Sumbangsih UMKM terhadap PDB menjadikan indikator pentingnya UMKM dalam peningkatan pertumbuhan perekonomian di Indonesia, Produk Domestik Bruto (PDB) merupakan indikator pertumbuhan perekonomian, dimana pertumbuhan ekonomi adalah proses kenaikan output perkapita dalam jangka yang panjang [3].

Pengembangan dunia usaha di Propinsi Banten tidak bisa dilepaskan dari peranan dunia usaha yang sudah ada, baik skala kecil maupun skala besar. Jumlah dunia usaha yang kian semakin banyak dan keberadaannya tersebar luar keseluruh wilayah, sekalipun distribusinya terkadang ditemui beberapa kendala. Salah satu pendorong pertumbuhan ekonomi adalah adanya iklim investasi yang baik ditunjang oleh produktifitas yang tinggi, perkembangan UMKM tersebut dapat dilihat pada tabel berikut ini : 
Tabel 2. Data Usaha Mikro, Kecil, Dan MenengahBerdasarkan Unit Usaha Di Provinsi Banten

\begin{tabular}{|c|c|c|c|c|}
\hline $\begin{array}{l}\text { MAILGUIII } \\
\text { ISSAHA }\end{array}$ & MIKLOO & KECIL. & MENENGGAH & IUIAL \\
\hline 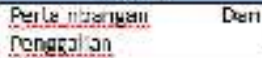 & 3,463 & 235 & 12 & 2,717 \\
\hline I keugzil Rongelation & $9,9.8$ & 9.912 & 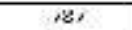 & $90,90 /$ \\
\hline Lylfit Gag Dan hit & 165 & 37 & $\boldsymbol{A}_{\mathrm{I}}$ & $26 \%$ \\
\hline B:ralliten & $3,73 \mathrm{~L}$ & CAI & 221 & 4,043 \\
\hline Perdesangar Dan [ceren & 330,055 & 23,352 & 2,605 & 127,120 \\
\hline 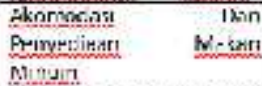 & 227,736 & 24,585 & 432 & 18082 \\
\hline 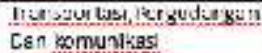 & $17 \sin$ & $2,1 \geqslant 4$ & 4.31 & $1 . \pi 9 \pi: 4$ \\
\hline Pelanla y K=uars=! & 599 & 798 & $4[37$ & 1.575 \\
\hline $\begin{array}{l}\text { Ireal } \\
\text { Dorspizan }\end{array}$ & $S_{i, T} T$ & $\therefore, 741$ & $\therefore \theta$ & $\therefore, y<7$ \\
\hline fise Fercldilkan & 2,44, & $2,5+4$ & 781 & $17,1: 8$ \\
\hline 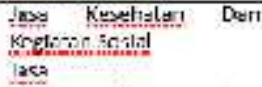 & 2,107 & 1,223 & $13 \times$ & $2,2=5$ \\
\hline 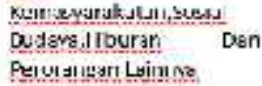 & $-9,912$ & 6,977 & $14=$ & $\pi, \pi+a$ \\
\hline 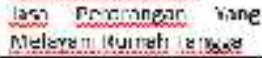 & $x, y=,$. & $\alpha$ & $\boldsymbol{E}$ & $4.18=9$ \\
\hline TOTAL & $x+4+4$ & 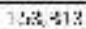 & $2,2(x-4)$ & $4 \times 4.118$ \\
\hline
\end{tabular}

Sumber : Dinas Koperasi dan UMKM Propinsi Banten 2012

Pada tabel diatas jelas memperlihatkan besarnya jumlah UMKM di Propinsi Banten mencapai 984,I I8 usaha, hal ini menjadi potensi bagi perkembangan perekonomian masyarakat agara pencapain kesejahteraan melalui UMKM dapat terwujud, hadirnya UMKM membawa kekuatan bagi perekonomian daerah sehingga mampu meningkatkan pendapatan asli daerah untuk operasional pembangunan, selain itu stabilitas usaha umkm sudah terukur dan teruji dalam menghadapi semua krisis ekonomi di tengah terpuruknya perekonomian bangsa namun UMKM mampu menjaga ketidakstabilan perekonomian saat itu. Banyak pengusahapengusaha yang kolaps bahkan bangkrut dan sektor perbankan yang menjadi penopang bagi pertumbuhan ekonomi nasional turut 'ambruk', khususnya bank-bank swasta nasional kecil. Sedangkan UMKM tetap bisa bertahan bahkan bisa menembus pasar yang selama ini dikuasai perusahaan besar. UMKM di Indonesia dapat bertahan di masa krisis ekonomi disebabkan oleh 4 hal yaitu: (I) sebagian UMKM menghasilkan barang-barang konsumsi (consumer goods), khususnya yang tidak tahan lama, (2) mayoritas UMKM lebih mengandalkan pada nonbanking financing dalam aspek pendanaan usaha, (3) pada umumnya UMKM melakukan spesifikasi produk yang ketat, dalam arti hanya memproduksi barang atau jasa tertentu saja, dan (4) terbentuknya UMKM baru sebagai akibat dari banyaknya pemutusan hubungan kerja di sektor formal. Keberlanjutan UMKM di Indonesia dapat ditinjau dari beberapa aspek, yaitu: (I) nilai tambah, (2) unit usaha, tenaga kerja dan produktivitas, (3) nilai ekspor [4]

Studitentangstrategikeunggulan bersaing pemasarandianalisissecaraempirik.menjelaskan bahwasemua keunggulan kompetitif memiliki kehidupan yang terbatas. Pertanyaannya Duplikasi tidak jika itu akan terjadi, tapi kapan. Secara umum, keberlanjutan Keunggulan kompetitif adalah fungsi dari tiga faktor: (I) tingkat kompetensi inti Keusangan karena perubahan lingkungan, (2) tersedianya barang pengganti Kompetensi inti, dan (3) meniru kompetensi inti [5].

Penelitian lainseperti Menunjukkanbahwa strategibersaingberpengaruhpositifdannyataterha dap pemberdayaansumberdayaperusahaan. penelitiantentangstrategikeunggulan

bersaingpemasarandenganpendekatan

keunggulanstrategibersaing

untukmenjelaskanbagaimana

perusahaandapatmenggunakanpotensi strategi (pemberdayaan membangun sumberdayayangkuatbagikeunggulan bersaing (competitiveadvantage). [6]

Sementara keuntungan finansial kadangkadang mungkin,UMKM mungkin tidak selalu menyadari hal ini atau merasa mudah untuk mengkonversi lingkungan keberlanjutan menjadi keunggulan kompetitif Keunggulan kompetitif adalah konsep fitur dan sumber daya yang memungkinkan organisasi melampaui Pesaing lainnya Dengan kata lain, keunggulan kompetitif membedakan perusahaan dalam satu atau Lebih banyak faktor yang memungkinkan perusahaan untuk melayani lebih baik, menciptakan nilai lebih, kepada pelanggan dan Oleh karena itu keberlanjutan lebih baik dari pada kompetitor. Untuk mencapai keunggulan kompetitif Perusahaan harus memiliki kemampuan untuk membuat rekomendasi yang dapat memberikan kebutuhan target Pasar lebih baik dari yang lain. [7] Keunggulan kompetitif termasuk faktorfaktor yang mendukung dan memastikan keberlanjutan organisasi bertahan hidup. Memang keunggulan kompetitif lebih banyak dari jumlah proposal yang menarik dibandingkan dengan Pesaing dari sudut pandang konsumen

Dalam kajian diatas, baiksecarateoritismaupunberdasarkanhasil hasilkajianempirismenunjukkanbahwamasihperlu dilakukan pengkajianterhadap faktorstrategikeunggulanbersaingsumberdayaper usahaan, implementasi strategik generik perusahaandankeberlanjutan usaha.Konsepdasarpenelitianini 
mengacupadakajian. [8]Penelitianinimengkaji kausalitasdiantaravariabel-variabeldan sekaligusinginmengetahuiperbedaan kerberlanjutan usahaantara kelompokpengelola,tenagakerjadengan penerapanstrategikeunggulanbersaing, sumber perusahaandanstrategigenerik untuk mempertanhakan keberlanjutan usaha khususnya UMKM.

Usaha mikro kecil dan menengah di Propinsi Banten dijadikan sebagai kajian penelitian dengan alasan, bahwa perekonomian saat ini sangat berkembang sangat pesat seiring tumbuhnya jumlah usaha mikro kecil dan menengah, jika analisis dari mulai perencanaan pembangunan ekonomi, khususnya perencanaan usaha mikro kecil dan menengah memerlukan perhatian yang besar dalam bidang pemasaran dan produksi. Dalam hal ini adanya peningkatan persaingan usaha UMKM di Propinsi Banten mengharuskan pemerintah dan pelaku ekonomi serta masyarakat diharapkan mempunyai kerja sama yang baik dan meningkatkan pelayanan melalui nilai tambah, produksi, kualitas dan penjualan agar tetap bertahan dan berkesinambungan.

Dengan demikian adanya kesadaran dan kebutuhan pelaku ekonomi dan masyarakat akan mempertahankan strategi keunggulan bersaing untuk dapat bertahan dan menemukan apa yang menjadi keunggulan bersaing dalam mempertahankan keberlanjutan usahanya.

\section{TINJAUAN PUSTAKA}

Analisis teori dan kerangka konseptual, menyatakan keunggulan bersaing sebuah strategi menciptakan nilai untuk sebuah perusahaan dan saat ini tidak diterapkan oleh pesaing potensialnya. Strategi keunggulan bersaing ini harus memiliki karakteristik sebagai berikut : rare (jarang digunakan), valuable (nilai lebih), dan not inimitable (tidak bisa ditiru) berdasarkan sumberdaya yang tersedia. Pada intinya keunggulan bersaing yang dimliki perusahaan harus dibandingkan dengan perusahaan lain dan tidak memiliki standar tertentu yang pasti. (Barney 200I dalam Birdsall, 2004), 1995, Yadong, 1996, Rebecca \& Duray 2000, Ireland \& Hitt 2007, Ozsomer 1995, Makinen 2000 dan Tikanen 1995). Day dan Wensley (1988) menyatakan bahwa keunggulan bersaing merupakan bentuk-bentuk strategi untuk membantu perusahaan dalam mempertahankan kelangsungan hidupnya. Pendapat tersebut didukung oleh Ferdinand (2003) yang menyatakan bahwa pada pasar yang bersaing, kemampuan perusahaan menghasilkan keberlanjutan, terutama keberlanjutan keuangan, sangat bergantung pada derajat keunggulan kompetitifnya.

Untuk melanggengkan keberadaannya, keunggulan bersaing perusahaan tersebut juga harus berkelanjutan, karena pada dasarnya perusahaan ingin melanggengkan keberadaannya. Keunggulan bersaing berkelanjutan merupakan strategi perusahaan untuk mencapai tujuan akhirnya, yaitu keberlanjutan yang menghasilkan keuntungan tinggi. Artinya, keunggulan bersaing berkelanjutan bukanlah tujuan akhir, tetapi merupakan sarana untuk mencapai tujuan akhir perusahaan, yaitu meningkatkan keberlanjutan perusahaan [9]Keunggulan bersaing berkelanjutan merupakan nilai yang mampu diciptakan oleh perusahaan untuk konsumennya secara terus menerus.

Keunggulan bersaing berkelanjutan ini dapat dilihat dari ketepatan perusahaan dalam menyediakan produk dipasar dan respon terhadap keluhan konsumen sepertikualitas produk, kebutuhan konsumen, pengusaan pasar baru serta adanya. Keunggulan bersaing pada dasarnya tumbuh dari nilai atau manfaat yang dapat diciptakan perusahaan bagi para pembelinya yang lebih dari biaya yang harus dikeluarkan perusahaan untuk menciptakannya. Keunggulan bersaing menggunakan cara- cara yang dapat dilakukan perusahaan untuk memilih dan mengimplementasikan suatu strategi generik guna mencapai dan melestarikan keunggulan bersaingnya. Lima faktor persaingan yang menentukan kemampulabaan perusahaan adalah pendatang baru, pemasok, pembeli, produk subtitusi dan persaingan diantara perusahaan yang ada

Sumberdaya Perusahaan mengacu atau kekuatan yang berada diluar organisasi yang mempengaruhi keberlanjutan perusahaan Robinson, 1989, Makinen 2000, Khairudin, 1998, Slater dan Narver 1996). Sumberdaya Perusahaan tipe sumber daya perusahaan menyatakan bahwa sumberdaya perusahaan dapat dikelompokkan menjadi dua yaitu aseet yang tangible dan asset intangible di mana semua asset dapat menciptakan keunggulan bersaing. (Robinson, 1989, Bhrust chaganti, 1999, Ken Matsuno, 2000; Varadarajan \& Fahy, 1996).

Menurut Porter's (2004), Strategi generik adalah pendekatan untuk mengungguli pesaing dalam industri: dalam struktur industri tertentu ini berarti bahwa semua perusahaan dapat memperoleh hasil laba yang tinggi, sedangkan di industri yang lain, keberhasilan dengan salah satu strategi generik mungkin diperlukan sekedar 
untuk mendapatkan hasil laba yang layak dalam artian absolut (Porter, 1994, Hill Jones 1998, Rubach \& McGee 200I) [10]

Research Gap I: yaitu tentang Issu Implemenasi Strategi Generik dengan strategi keunggulan bersaing. Sejumlah studi telah menunjukkan pentingnya hubungan antara Strategi keunggulan bersaing dengan Implementasi strategi Generik Porter, (1994). Pendapat tersebut bahwa unit bisnis yang mempunyai strategi keunggulan bersaing memiliki tingkat hasil penjualan yang tingi melalui kombinasi strategy low cost dan strategy differensiasi. Penelitian lain White (1996) menunjukkan bahwa penggunaan strategi keunggulan bersaing berpengaruh positif signifikan terhadap impelementasi strategi bersaing dan keberlanjutan perusahaan. Namun demikian ada beberapa penelitian lain mempunyai pendapat yang berbeda seperti Ireland dan Hitt, (2007), Brush dan Chaganti (1997), [II] bahwa kesuksesan penerapan strategi bersaing tidak tergantung pada strategi generik perusahaan akan tetapi juga merupakan faktor kekuatan yang effektif berpengaruh terhadap keberlanjutan perusahaan yang lebih baik. Perbedaan pendapat tentang pengaruh hubungan strategi keunggulan bersaing dengan penerapan strategi generik.

Pada penelitian selanjutnya Foss (1997), (Rubach dan McGee(200I) menyatakan bahwa hasil penelitian yang sudah dilakukan masih menunjukkan adanya perbedaan dan belum menjelaskan kenapa perbedaan tersebut terjadi. Ireland dan Hitt (1997) adanya perbedaan hasil studi menurut analisisnya karena para peneliti belum mengkaji lebih lanjut adanya variabel independen (strategi keunggulan bersaing) dengan variabel dependen (strategi generik dan keberlanjutan).

Research Gap 2: yaitu tentang Isu Pengaruh sumber daya perusahaan memeliki hubungan dengan strategi keunggulan bersaing. Studi telah menunjukkan bahwa pengaruh antara sumber daya perusahaan strategu keunggulan bersaing. Hasil analisis diatas dapat diakatakan perlu adanya studi memperjelas sumber-sumber perbedaan keberlanjutan perusahaan. Berdasarkan uraian di atas ini dilakukan untuk memperjelas apa yang menyebabkan sumbersumber perbedaan untuk menciptakan nilai perusahaan dan bagaimana untuk mengembangkan potensi lingkungan operasi perusahaan dapat menurunkan keberlanjutan perusahaan. Sumberdaya Perusahaan dapat memberi efek (pengaruh) positif terhadap keberhasilan keberlanjutan perusahaan
Robinson, (1998). Studi ini juga diharapkan dapat memberi kontribusi dalam pengembangan disiplin IImu Manajemen Stratejik, untuk mencapai sasaran secara lebih sukses. Studi ini dikembangkan dengan menggunakan pendekatan beberapa teori antara antara lain Market Based Niew (Contigency Theory), Resource Based View of the Firm. Robinson, (1998). Penelitian lain tentang lingkungan operasi perusahaan juga disampaikan Slater dan Narver (1996), Rebecca et al. (200I), Khairudin H, (2003) hasil penelitian tersebut masih menunjukkan adanya perbedaan dan belum menjelaskan adanya perbedaan, hasil studi bukan berarti studi tersebut tidak berlaku.

Menurut Robinson, (1998); Rebecca et al. (200I) bahwa hasil studi tersebut menyatakan, peneliti belum mengkaji lebih lanjut adanya variabel Sumberdaya Perusahaan sebagai variabel moderating hubunganantar strategi keunggulan bersaing terhadap keberlanjutan perusahaan. Dalam kajian Slater dan Narver (1996), Khairudin.H (2003) secara empirisnya,penelitian Ozsomer dan Yadong(1999) menyatakan bahwa variabel sumber daya perusahaan mempunyai pengaruh tidak langsung, antara strategi keunggulanbersaing terhadap keberlanjutan perusahaan. Slater dan Narver (1996), Khairudin H. (2003), Maridjo, (2004) dalam kajiannya, menunjukkan bahwa lingkungan operasi berperan penting sebagai mediator dalam hubungan antara strategi keunggulan bersaing dengan sumberdaya perusahaan dan keberlanjutan perusahaan

Research Gap 3: yaitu tentang Issu Pengaruh Sumberdaya perusahaan dan Implementasi Strategi Generik Sejumlah studi telah menunjukkan pentingnya pengaruh antara pemberdayaan sumberdayaperusahaan dengan implementasi strategi generic. Brush danCahaganti, (1997), Makinen (2000). Pendapat tersebut didukung oleh peneliti lainnya, Robinson, (1998), Ken Matsuno John Mentzer (1999), Ozsomer (1998) yang menunjukkan bahwa sumberdaya perusahaan berpengaruh terhadap proses penerapan memilih strategi generik. Namun beberapa peneliti, Ken Matsuno, (1999) mempunyai pendapat yang berbeda yang menemukan bahwa kesuksesan tidak tergantung pada mengimplementasikan strategi generik dalam mengintegrasikan dan memberdayakan sumberdaya perusahaan yang stratejik.

Perbedaan pendapat tentang pengaruh sumberdaya perusahaan terhadap implementasi strategi generik, diantara beberapa 
peneliti,disebabkan adanya perbedaan konsep yang menggunakan yaitu antar market based view dan resource based view the Firm.Perbedaan kedua pandangan ini terletak pada penekanan prioritas perhatian manajerial dalam menentukan keputusan organisasi perusahaan dalam mencapai tujuan yang berbeda (Joh dan Hill, 200I). Oleh karena itu, keputusan manajerial dalam menentukan pilihan strategi generik berbeda sesuai dengan karakteristik sumberdaya perusahaanyang dimiliki. Menurut Robinson, (1998), Brush dan Chaganti (1998) menyatakan bahwa strategi kombinasi (strategi generik) melalui pemberdayaan sumberdaya perusahaan merupakan faktor kekuatan yang efektif dalam keberlanjutan perusahaan.[13]

Research Gap 4: yaitu tentang Issu Strategi keunggulan Bersaing Implementasi strategi Generik terhadap Keberlanjutan usaha Sejumlah studi telah menunjukkan pentingnya pengaruh antara penerapan strategi kenggulan bersaing, sumberdaya Peruasahaan, implementasi strategi generik dengan keberlanjutan perusahaan. Ireland dan Hitt,(1997), Slater dan Narver, (1996), Brush dan Chaganti (1997), Ozsomer (1998), Yadong(1999), Makinen, (2000).
Beberapa peneliti mempunyai pendapat yang berbeda seperti Ireland dan Hitt (1997) Luo (1998), Yadong (1999) yang menemukan keberhasilan perusahaan tidak tergantung pada penerapan strategi keunggulan bersaing, sumberdaya perusahaan dan penerapan strategi generik yang jitu.Perbedaan pendapat terjadi disebabkan karena belum mengkaji dan belum menjelaskan kenapa perbedaan tersebut terjadi.

Menurut Brush dan Chaganti (1997), Rebecca,et al. (200I) menyatakan bahwa adanyavariabel independen tidak berpengaruh tidak langsung terhadap variabel dependen dan sebaliknya ada variabel yang berpengaruh berpengaruh positif terhadap variabel dependen Perbedaan sumber daya perusahaan dapat menyebabkan perbedaan dalam keberlanjutan. Pengkajian Ken Matsuno, John Mentzer, (1998), Rubach dan (Mc Geen, 200I), (Khairudin dan Maridjo 2004).

Untuk itu dalam penelitian ini dapat ditarik hipotesis yang dikembangkan dari hasil kajian pustaka dan diuji dalam penelitian dapat dikemukakan sebagai berikut:

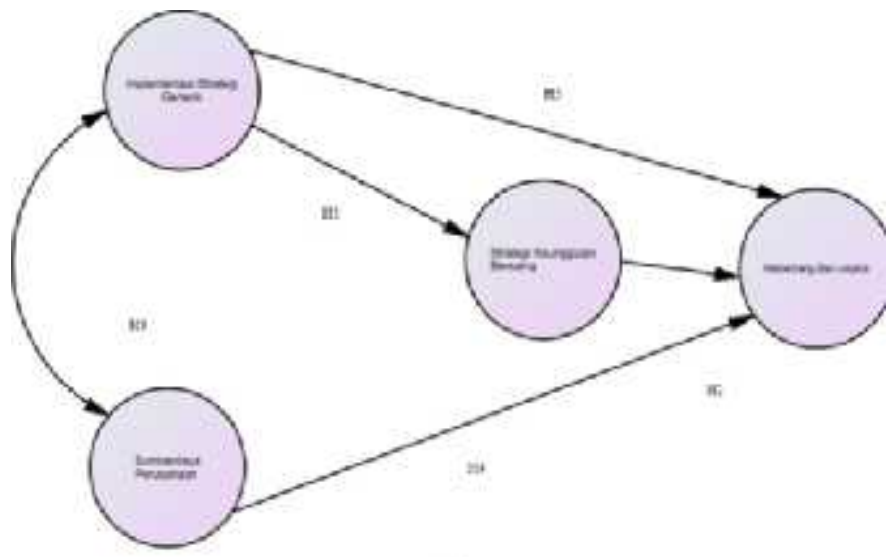

Gambar I. Kerangka Hipotesis

$\mathrm{H}_{\text {I. }} \quad$ Implementasi strategi generik berpengaruh positif terhadap strategi keunggulan pemasaran usaha

$\mathrm{H}_{2}$. Strategi keunggulan bersaing berpengaruh positif terhadap keberlanjutan usaha

$\mathrm{H}_{3}$. Sumberdaya perusahaan berpengaruh terhadap implementasi strategi generik usaha

$\mathrm{H}_{4}$. Sumberdaya perusahaan, berpengaruh positif terhadap keberlanjutan usaha

$\mathrm{H}_{5}$. Implementasi strategik generik berpengaruh positif terhadap keberlanjutan usaha

\section{METODOLOGI PENELITIAN}

Rancangan penelitian ini dengan pendekatan metode kuantiitatif dengan alat analisis SEM. Uji coba mengumpulkan data lapangan industri pengolahan di Propinsi sampel sebanyak 170 UMKM se-Propinsi Banten. Tahap berikutnya entri data dan tabulasi data dengan program SPSS. Teknik pengukuran yang digunakan dikembangkan oleh Skala Likert Uji Validitas dan Reliabilitas dengan alat uji (I) ChiKuadrat, (2) RMSEA, (3) GFI, (4) AGFI, (5) CMIN DF Uji Reliabilitas dengan reliabilitas konstruk 


\section{HASIL PENELITIAN}

\section{Uji Instrumen}

Keseluruhan terdapat 5 jalur hubungan atau pengaruh antar konstruk yang diuji yang semuanya pengaruh langsung maupun pengaruh tak langsung. Secara keseluruhan akan diuraikan penjelasan mengenai pengujian hipotesis ke delapan pengaruh sebagai berikut:

Tabel. 3 Hasil Pengujian Hipotesis Penelitian

\begin{tabular}{|c|c|c|c|c|c|c|c|c|}
\hline \multirow{2}{*}{ Hipotes is } & \multirow{2}{*}{$\begin{array}{c}\text { Variabel } \\
\text { independent }\end{array}$} & \multirow{2}{*}{$\begin{array}{c}\text { Variabel } \\
\text { dependent }\end{array}$} & \multicolumn{3}{|c|}{ Koefesien Jalur Direct Effect } & \multicolumn{3}{|c|}{ Koefesien Jalur Indirect Effect } \\
\hline & & & t-standardize & p-value & Keterangan & $\begin{array}{c}\text { Variabel } \\
\text { Moderating } \\
\end{array}$ & $\begin{array}{c}\text { Standardiz } \\
\mathrm{e}\end{array}$ & $\begin{array}{c}\text { Keteranga } \\
\mathrm{n}\end{array}$ \\
\hline H1 & $\begin{array}{c}\text { Implementasi } \\
\text { strategi generik }\end{array}$ & $\begin{array}{c}\text { Strategy } \\
\text { Keunggulan } \\
\text { Bersaing } \\
\end{array}$ & 0,000 & 0,000 & $\begin{array}{c}\text { non } \\
\text { signifikan }\end{array}$ & n.a & 0,000 & ditolak \\
\hline $\mathrm{H} 2$ & $\begin{array}{c}\text { Strategy } \\
\text { Keunggulan } \\
\text { Bersaing } \\
\end{array}$ & $\begin{array}{c}\text { keberkelanjuta } \\
\text { n Usaha }\end{array}$ & 0,491 & 0,000 & signifikan & n.a & 1,000 & diterima \\
\hline $\mathrm{H} 3$ & $\begin{array}{l}\text { Sumber daya } \\
\text { Perusahaan }\end{array}$ & $\begin{array}{c}\text { Implementasi } \\
\text { strategi } \\
\text { generik }\end{array}$ & 0,611 & 0,000 & signifikan & n.a & 0,300 & diterima \\
\hline $\mathrm{H} 4$ & $\begin{array}{c}\text { Sumber daya } \\
\text { Perusahaan }\end{array}$ & $\begin{array}{c}\text { keberkelanjuta } \\
\text { n Usaha }\end{array}$ & 0,412 & 0,023 & signifikan & n.a & 0,021 & diterima \\
\hline H5 & $\begin{array}{c}\text { Implementasi } \\
\text { strategi generik }\end{array}$ & $\begin{array}{c}\text { keberkelanjuta } \\
\text { n Usaha }\end{array}$ & 0,228 & 0,000 & signifikan & n.a & 0,153 & diterima \\
\hline
\end{tabular}

Keterangan : Signifikan level $5 \%$ nilai t-tabel $\left(I^{\wedge}\right)$

I. Variabel Implementasi strategi generik tidak berpengaruh langsung terhadap strategi keunggulan bersaing sebesar 0,00

2. Variabelstrategikeunggulanbersaing pemasaranberpengaruhlangsung terhadap varhiabel keberlanjutan usaha. Pengaruh langsung terhadap keberlanjutan dengan nilai sebesar0,49 I Halinimenunjukkan bahwasemakinkuatstrategikeunggulanbersai ngditerapkanperusahaan semakinkuatpengaruhnyaterhadap keberlanjutan usaha.

3. VariabelSumberdaya Perusahanberpengaruhtaklangsung danpositifterhadapimplementasi strategigenerik.Pengaruhlangsung terhadapimplementasistrategigenerik sebesar0,6 I I. Halinimenunjukkan bahwasemakintinggisumberdaya perusahaanyangdilakukanperusahaansemaki ntinggipengaruhnyaterhadap Implementasi strategi generik.

4. Variabelpemberdayaansumberdaya perusahaan berpengaruh langsung positif terhadap keberlanjutan usaha. Pengaruh langsung terhadap keberlanjutan usaha sebesar 0,4I2. Hal ini menunjukkan bahwasemakin baik sumberdaya perusahaan dilakukan perusahaan semakin kuat pengaruhnya terhadap keberlanjutan usaha.

5. Variabel Implementasi strategi generik berpengaruh langsung terhadap keberlanjutan usaha. Sebesar 0,228 Pengaruh tidak langsung disebabkan ekonomi daya beli rendah sehingga mengaki-batkan penurunan keberlanjutan usaha. Hal ini menunjukkan bahwa semakin lemah implementasi strategi generik yang diterapkan perusahaan semakin lemah pengaruhnya terhadap keberlanjutan usaha

\section{PengaruhStrategiKeunggulanBersaingter hadapStrategiGenerik}

Pembahasan pengaruh strategi keunggulan bersaing pemasaran terhadap Implementasi strategi generik adalah untuk menjawab rumusan masalah yang ketujuh secara parsial. Hasil analisis dengan menggunakan Struktural Equation Modeling (SEM) serta Confirmator Factor Analysis (CFA) menunjukkan bahwa terdapat pengaruh negatif (berlawanan arah) antara strategi keunggulan bersaing terhadap Implementasi strategi generik dengan besaran kosefisien $(0,300)$ pada level of significance $5 \%$. Dengan demikian dapat disimpulkan bahwa, yang menyatakan bahwa strategi keunggulan bersaing pemasar berhubungan terhadaplmplementasi strategi generik tidak terbukti kebenaran dan didukung oleh fakta.

Hasil penelitian ini pendapat Rebecca Duray, (2000) penelitian ini menyatakan untuk mengetahui hubungan dan pengaruh strategi bersaing pemasaran implementasi strategi generik terhadap keberlanjutan perusahaan Variabel strategi keunggulan bersaing 
menunjukkan dimensi yang luas dengan indikator: keunggulan produk keunggulan pelanggan, keunggulan pesaing, keunggulan pemasok. Sedangkan strategi manufaktur dengan item: orientasi pasar, fleksibiltas, kualitas dan pengiriman. Dari data 100 sampel perusahaan logam dan alat elektronik dengan analisis Cluster maka ditemukan bahwa strategi keunggulan bersaing mempengaruhi keberlanjutan perusahaan. Fakta menunjukkan bahwa strategi bersaing (differensiasi dan kualitas) memberikan keberlanjutan yang tinggi bagi perusahaan. Dengan memperhatikan bukti-bukti empirik tersebut maka hipotesis I antara implementasi strategi generik tak berpengaruh positif terhadap strategi keunggulan bersaing tidak terbukti jabawannya

\section{PengaruhStrategiKeunggulanBersaingPe masaranterhadapkeberlanjutan usaha UMKM}

Padapenelitianselanjutnyatentang

StrategikeunggulanbersaingolehFoss (1997) hasil studi pengaruhStrategikeunggulanbersaing terhadapKeberlanjutanusaha. Hasilpenelitian

Dierik\&Coll(dalamPowel I998), Hart danMiles Misberg, 1998.Sudah dilakukan menunjukkan,bahwaadanyaperbedaanyangmenjel askanstrategikeunggulan

bersaingberpengaruhsecaralangsung

maupuntaklangsungterhadapKeberlanjutan

perusahaan.

Hasilanalisisdenganmenggunakan

StrukturalEquationModeling(SEM)serta

ConfirmatoryFactorAnalysis

menunjukkanbahwaterdapatpengaruh

yang

signifikanantaraStrategi

keunggulanbersaingterhadapKeberlanjutan

usahadengankoefisien 0.537)padalevelofsignificanc

e5\%.Dengandemikian

dapatdisimpulkanbahwaH $\mathrm{H}_{2}$,yang

menyatakanbahwakeunggulanstrategi

bersaingpemasaranberpengaruh

terhadapkeberlanjutan

usaha

tidakterbuktikebenarnyaataudidukung oleh fakta.

$$
\text { Hasil penelitian oleh Rebecca }
$$

Duray,(2000) judul

ManufacturingStrategyinContext:Environment,"Com petetiveStrategyandManufacturingStrategy"

penelitianiniuntukmengetahuihubungan

danpengaruhstrategibersaingdan Keberlanjutan.

Variabel strategi bersaing menunjukkan indikator : keunggulan kepemimpinan

biaya, differensiasi,

sedangkanstrategimanufakturdengan

itemkualitasproduk,pelanggan,pesaing

danpengirimandanharga,dengananalisisCovarian, hasitersebut menunjukkanbahwastrategi bersaingdan strategi manufaktur mempengaruhi Keberlanjutanperusahaan.Faktamenunjukkanbah wa strategi keunggulan bersaing memberikankeberlanjutanyangtinggibagi perusahaan.

\section{PengaruhPemberdayaanSumberdayaPeru sahaanterhadapImplementasiStrategiGen erik \\ PembahasanpengaruhSumberdaya}

perusahaanterhadaplmplementasi strategi generik adalah untuk menjawab rumusan masalah yang kelima secara parsial. Hasil analisis dengan menggunakan Structural Equation Modeling (SEM) serta Confirmatory Factor (CFA) menunjukkan bahwa terdapat pengaruh positif dan signifikan antara sumberdaya perusahaan terhadap Implementasi strategi generik dengan koefisien pengaruh sebesar $(0,375)$ pada level of significance $5 \%$. Dengan demikian dapat disimpulan bahwa sumberdaya perusahaan berpengaruh terhadap Implementasi Strategi generik terbukti atau mendukung oleh fakta.

Sumberdaya perusahaan diukur dalam 6 (indikator) dan 15 item terdiri: dari sumber keuangan, sumber fisik, sumber keorganiasaian, sumber reputasi, SDM dan sumber teknologi.Pengaruhkeenam indikator dengan 15 item tersebut terhadapimplementasistrategigenerik dankeberlanjutan usaha UMKM. Berdasarkandataempirik tersebut maka sumberdaya perusahaan yang dilaksanakan berpengaruh terhadap implementasistrategigenerikterhadap keberlanjutanyangdicapaiperusahaanterbukti kebenarannya.

\section{PengaruhSumberdayaPerusahaanterhada pKeberlanjutanUsaha UMKM}

Pembahasan pengaruh sumberdaya perusahaan terhadap Keberlanjutan usaha UMKM untuk menjawab rumusan masalah yang pertama secara parsial. Hasil analisis dengan menggunakan Struktural Equation Modeling (SEM) serta sumberdaya terhadap keberlanjutan usaha kecil. Identifikasi penggunaan strategi fokus berdasarkan apakah perusahaan menjual secara lokal. Keberlanjutan usaha UMKM yang diukur dengan tiga cara: Arus kas pada tahun sebelumnya, Pertumbuhan tenaga kerja, keberlanjutan usaha. Tiga jenis sumberdaya diukur dengan berdasarkan ada: sistem pengambilan keputusan, penggunaan staf terlatih penggunaan penggunaan pelaporan tertulis dan operasi dalam bisnis. Keberlanjutan usaha 
UMKM terbukti kebenarannya atau dari fakta yang mendukung.

\section{PengaruhImplementasiStrategiGenerikte rhadapKeberlanjutanUsaha UMKM}

Hasil analisis dengan menggunakan

Struktural Equation Modeling (SEM) serta

Confirmatory Factor Analysis (CFA) menunjukkan bahwa terdapat pengaruh positif dan signifikan antara Implementasi strategi generik terhadap keberlanjutan usaha, dengan koefisien pengaruh sebesar $(0,157)$ pada level of significance $5 \%$. Dengan demikian dapat disimpulkan bahwa Implementasi strategi Generik berpengaruh terhadap Keberlanjutan usaha UMKM. terbukti kebenarnnya atau didukung oleh fakta.

Hasil penelitian oleh Ireland dan Hitt (1997) "Permonfance Strategies for High-Growth Entrepreneurial Firms" Tujuan penenlitian ini untuk mengetahui pengaruh antara strategi biaya rendah, strategi diferensiasi, strategi kualitas tinggi terhadap keberlanjutan perusahaanVariabel bebas; strategi biaya rendah, diferensiasi, strategi kualitas tinggi dan variabel terikatnya keberlanjutan perusahaan. Perusahaan mengalami pertumbuhan dengan cepat, dengan analisis metode analisis statistik regresi, hasil penelitian menunjukkan bahwa strategi biaya rendah, diferensiasi serta keunggulan kualitas tinggi berpengaruh positif signifikan terhadap keberlanjutan perusahaan. Hasil penelitian ini juga mendukung penelitian sebelumnya yang dilakukan oleh Norton, (1999) yang menyatakan bahwa Sumberdayaperusahaan, interaksi kelompok kerja dan strategi mampunyai hubungan yang positif terhadap keberlanjutan perusahaan. Hasil penelitian Brush dan Chaganti (1997) menyatakan penelitian sekaligus mengkaji hubungan sumberdaya perusahaan dimana semakin tinggi implementasi strategi generik maka semakin lemah pengaruh terhadap keberlanjutan usaha, terbuktikebenarannya.

\section{PENUTUP}

Dari keseluruhan hasil penelitian ini dapat dikemukakan beberapa kesimpulan dimana penelitian ini telah menunjukkan bahwa berkelanjutan usaha merupakan proses yang memenuhi kebutuhan kompetitif dari para manager perusahaan untuk mengorbankan kemampuan organisasi dalam memenuhi kebutuhan persaingan usaha di masa depan.
Para manajer atau pimpinan pada usaha UMKM di Propinsi Banten harus memahami pentingnya pemasaran berorientasi pelanggan dengan tujuan pimpinan memiliki pengalaman dalam mengelola UMKM, pengalaman juga sangat mempengaruhi pandangan dalam mengelola bisnis untuk mempertahankan keberlanjutan usahanya.

Dengan hasil penelitian dari variabel Implementasi strategi generik, strategi keunggulan, pemberdayaan sumberdaya berpengaruh terhadap keberlanjutan usaha UMKM. Dimana keberlanjutan usaha UMKM merupakan hal yang penting bagi keberhasilan perusahaan, terutama mewujudkan tujuan keuangan superior. Tidak hanya perusahaanperusahaan besar saja yang membutuhkan keberlanjutan usaha, perusahaan kecil dan menengah (UMKM) juga penting menciptakan berkelanjutan usaha setidaknya dalam mempertahankan kelangsungan usahanya bahwa implementasi strategi generik tidak berpengaruh terhadap strategi keunggulan bersaing hal ini disebabkan pada pimpinan usaha untuk menguasai tujuan dan misi dari perusahaan yang sifatnya tertutup.

Adanya variabel-variabel lain dapat dibuktikan berpengaruh variabel lain (strategi keunggulan bersaing, sumber daya perusahaan, implementasi strategi generik, terhadap keberlanjutan usaha) dapat dibuktikan mampu ditingkatan baik secara langsung dengan pengukuran strategi keunggulan bersaing mempengaruhi keberlanjutan penuh secara langsung dan dipengaruhi semakin kuat melalui penguatan sumberdaya perusahaan.Implementasi strategi generik semakin baik dalam mempengaruhi keberlanjutan usaha UMKM.

Penelitian ini dapat memiliki dampak pada peningkatan kapasitas UMKM khususnya di Propinsi Banten untuk lebih meningkatkan kembali strategi keunggulan, pemberdayaan sumber daya, implementasi strategik generic sehingga mampu mempertanhakan keberlanjutan usahanya baik di tengah kondisi ekonomi nasional yang tidak stabil sehingga umkm mampu menjadi solusi untuk dapat memberikan kontribusi dalam mempertahankan stabilitas ekonomi baik nasional maupun daerah, yang tujuannya untuk mewujudkan kesejehteraan masyarakat, dengan demikian jelas bahwa strategi dianggap dalam hal tidak hanya aplikasi yang efisien dan efektif sumber daya competitive tapi dari eksploitasi dari potensi kemampuan esensial yang diberikan oleh sumber daya strategis.

Pemahaman hubungan strategi untuk pengenalan sumber daya perusahaan. Dimana 
fokus analisis untuk keunggulan bersaing terbaik berdasarkan daripada keuntungan dengan alasankeuntungan adalah konsep akuntansi berdasarkan definisi sumber daya dengan menggunakan keuntungan, quantification asset didasarkan pada biaya historis daripada konsep yang lebih luas potensi penggunaan, keuntungan tidak mungkin untuk mengidentifikasi kualitas aset di luar nilai-nilai angka yang sederhana.

Adapun Proses pengembangkan UMKM melalui konsep yang dinamis dapat dilakukan melalui sebagai berikut :

I. Keunggulan kompetitif yang berkelanjutan harus berorientasi pada pelayanan karena tidak ada organisasi sumber daya tak terbatas dengan batasan seperti itu, manajemen sadar dari yang ada sumber daya diperlukan.

2. Keunggulan kompetitif yang berkelanjutan perlu berbasis pada kebutuhan dimana aktivitas ekonomi dari organisasi harus peduli dengan kebutuhan pasar untuk barang dan layanan yang dihasilkan dari ekonomi semacam itu aktivitas

3. Keunggulan kompetitif yang berkelanjutan selalu berorientasi pada masa depan, menempatkan dirinya di luar Manajemen sehari-hari untuk jangka panjang Pengembangan sumber daya untuk mewujudkannya keunggulan strategis

Perkembangan dan tepat waktu dalam pengenalan sumber daya strategis melalui percepatan persaingan, ini harusnya dilihat melalui paradigma baru karena yang berlaku, pendekatan optimasi yang sempit telah menciptakan visi perusahaan yang berpandangan ke masa depan. Kebutuhan organisasi dengan optimasi pola pikir, sumber infrastruktur sebagian besar telah dirancang untuk memajukan stabilitas. Jelas, persaingan telah masuk ke era baru, masalahmya pada infrastruktur yang menjadi masalah perusahaan tidak bisa bergerak secara efektif, untuk itu menggabungkan sumber daya strategis dapat dilihat dari Prinsip-prinsip sebagai berikut :

I. Sumber daya perusahaan harus diregenerasi lebih cepat dari yang digunakan.

2. Sumber daya perusahaan harus digunakan lebih cepat daripada pengganti tersedia.

3. Sumber daya perusahaanyang seharusnya dianggap untuk divestasi lebih cepat dari pada tingkat penerimaan lingkungan. [14]

Adapun hal-hal yang perlu dilakukan oleh pemerintah dalam rangka mendukung keberlangsungan usaha UMKMKM, khususnya pemerintah daerah Propinsi Banten, yang diantaranya adalah:

I. Memperhatikan penyediaan infrastruktur yang baik fisik (seperti jalan raya, listrik dan fasilitas komunikasi, dan pelabuhan) dan nonfisik (seperti bank/lembaga pendanaan, pusat informasi, lembaga pendidik- an/pelatihan, litbang/lab), mulai di tingkat desa, kecamatan, kabupaten hingga di tingkat provinsi.

2. Melakukan proses pemberdayaan kembali semua sentra-sentra UMKM yang ada perlu diremajakan dengan antara lain menggantikan mesin-mesin dan alat-alat pengujian/lab yang sudah usang dengan yang baru.

3. Adanya bantuan pendanaan memang penting, namun sudah saatnya penekanan dari kebijakan atau program-program pemerintah untuk membantu perkembangan UMKM lebih pada peningkatan pendidikan pengusaha dan pekerja, pengembangan teknologi, dan peningkatan kemampuan inovasi. Selain itu, UMKM baik yang hanya melayani pasar domestik maupun yang menjual produkproduknya ke pasar luar negeri perlu dibantu sepenuhnya (misalnya dengan penyediaan lab. untuk pengujian kualitas barag) agar bisa mendapatkan label Standarisasi Nasional Indonesia (SNI) untuk meningkatkan kualitas produk dan berarti juga daya saing UMKM. Untuk maksud ini, perlu adanya intensif agar terjalin kerjasama yang erat antara UMK setempat dengan perguruan tinggi, lembaga pendidikan/pelatihan dan litbang setempat sehingga terjadi peralihan teknologi dan pengetahuan ke UMKM.

4. Prioritas peningkatan keterkaitan produksi lewat misalnya subcontracting antara UMKM dan UB (usaha besar), termasuk perusahaanperusahaan asing (PMA) yang beroperasi di daerah. Berdasarkan fakta bahwa sulit mendapatkan UMKM lokal yang siap sebagai pemasok bagi UB/PMA karena keterbatasan teknologi dan pengetahuan, maka untuk mencapai tujuan ini, pemerintah daerah bersama-sama dengan pihak swasta seperti Kamar Dagang dan Industri Daerah (Kadinda), asosiasi bisnis, himpunan pengusaha, dan universitas harus sepenuhnya membantu UMKM dalam meningkatkan kemampuan mereka sebagai pemasok yang kompetitif dan efisiensi

5. Perlu diupayakan agar semua UMK di manapun lokasinya mendapatkan akses sepenuhnya ke informasi mengenai pasar dan lainnya, teknologi, pendidikan/pelatihan, fasilitas perdagangan, dan perbankan; tentu dengan tidak menghilangan penilaian obyektif mengenai kelayakan usaha dari UMK bersangkutan. 


\section{DAFTAR PUSTAKA}

[1]. Lembaga Pengembangan Perbankan Indonesia dan Bank Indonesia, 2015, Profil Bisnis Usaha Mikro Kecil dan Menengah (UMKM), diakses http://www.bi.go.id/id/umkm/ pada Tanggal 14 Februari 2017

[2] Rencana Strategis Kementrian Koperasi dan Usaha Kecil dan Menengah Repubilk IndonesiaTahun 20I2-20I4

[3] Boediono, 1999. Teori Pertumbuhan Ekonomi, Seri Sinopsis Pengantar Ilmu ekonomi, Edisi I, Cetakan Ke 6.BPFE.Jogyakarta.

[4] Rahmana, Arif, 2009, Peranan Teknologi Informasi Dalam peningkatan Daya Saing Usaha Kecil Menengah.Seminar Nasional Aplikasi Teknologi Informasi (SNATI 2009), ISSN: 1907-5022, Yogyakarta

[5] M. Makhija, 2003, Comparing the resource-based and market-based view of the firm: Empirical evidence from Czech privatization, Strategic Management Journal, 24: 433-45 I; P. L. Yeoh \& K. Roth, 1999, An empirical analysis of sustained advantage in the U.S. pharmaceutical industry: Impact of firm resources and capabilities, Strategic Management Journal, 20: 637-653

[6] Barney, J. 1991. Firm esources and Sustained Competetive Advantage. Dalam A.A Thompson \& A.J Sricland III. Crafting and Implementing Strategy New York: Irwin \& McGraw Hill Book Co.

[7] H. Perzon, Assessing the Readiness for Implementing e-CRM in B2B Markets, Master Thesis, Lulea University of Technology (2008)

[8] P.L. Kam WA. The critical success factors of customer relationship management (CRM) technological initiatives, Master's Thesis, Concordia University (200I).

[9] Ferdinand, Augusty, 2003, Suistainable Competitive Adventage, Badan penerbit universitas Dipenogoro, semarang.

[10] Porter, Michael E., 1994. Keunggulan Bersaing, Bina Rupa Aksara, Jakarta.

[II] Hitt, Ireland (2007), Strategic Management Competitiveness And Globalization Thomson Higher Education 5191 Natorp Boulevard
Mason, OH 45040 USA. Library of Congress Control Number: 20059II 294

[12] Robinson, Sandra. L., \& Bennett, Rebecca J. 1995. A typology of deviant workplace behaviors: A multidimensional scaling study.Academy of Management Journal, 38(2): 555-572

[13] Bruce A.McDaniel. 2005. A Contemporary View of Joseph A. Schumpeter's Theory of the

[14] Kazem Chaharbaghi and Richard Lynch, 1999, Sustainable competitive dvantage: towards a dynamic resource-based strategy Management Decision 37/I [1999] 45-50 